\title{
Tectonic controls on the geomorphic evolution of alluvial fans in the Piedmont Zone of Ganga Plain, Uttarakhand, India
}

\author{
Pradeep K Goswami*, Charu C Pant and Shefali Pandey \\ Department of Geology, Kumaun University, Nainital 263 002, Uttarakhand, India. \\ *e-mail: drpgoswami@yahoo.com
}

The Piedmont Zone is the least studied part of the Ganga Plain. The northern limit of the Piedmont Zone is defined by the Himalayan Frontal Thrust (HFT) along which the Himalaya is being thrust over the alluvium of the Ganga Plain. Interpretation of satellite imagery, Digital Terrain Models (DTMs) and field data has helped in the identification and mapping of various morphotectonic features in the densely forested and cultivated Piedmont Zone in the Kumaun region of the Uttarakhand state of India. The Piedmont Zone has formed as a result of coalescing alluvial fans, alluvial aprons and talus deposits. The fans have differential morphologies and aggradation processes within a common climatic zone and similar litho-tectonic setting of the catchment area. Morphotectonic analysis reveals that the fan morphologies and aggradation processes in the area are mainly controlled by the ongoing tectonic activities. Such activities along the HFT and transverse faults have controlled the accommodation space by causing differential subsidence of the basin, and aggradation processes by causing channel migration, channel incision and shifting of depocentres. The active tectonic movements have further modified the landscape of the area in the form of tilted alluvial fan, gravel ridges, terraces and uplifted gravels.

\section{Introduction}

The Ganga Plain occupies the central part of the Indo-Gangetic plains (figure 1). In the west it is separated from the Indus Plain by the DelhiAravalli Ridge and in the east from Brahmaputra Plain by the Rajmahal Hills (figures 1 and 2). Morphologically, the Ganga Plain is a shallow asymmetrical depression with a gentle easterly slope wherein six distinct regional geomorphic surfaces, related to climatic events of Late Pleistocene-Holocene time, have been identified by Singh (1996) (figure 3). Based on morphostratigraphy and Optically Stimulated Luminescence (OSL) dating of sediments, Singh (1996, 2004) and Srivastava et al (2003) proposed the following hierarchy and chronological scheme for these surfaces.
The oldest of the surfaces is the Upland Interfluve Surface $\left(T_{2}\right)$, which formed during the early Late Pleistocene $(128-74 \mathrm{ka})$. It consists of finegrained material and occurs as vast raised interfluve regions in the northern parts of the basin. The north and northeasterly sloping surface to the south of the Yamuna River in the western part and south of the Ganga River in the eastern part of the basin is designated as the Marginal Plain Upland Surface (MP). This surface is equivalent to the $T_{2}$ surface of the north and consists of highly oxidized sediments derived from the Peninsular Craton. Over the $T_{2}$ surface the Megafan Surfaces (MF) were deposited during middle Late Pleistocene (74-35 ka). The megafans are very lowrelief fan like features that occupy large areas of the northern and central parts of the basin. The MF is a relict geomorphic surface that is now modified by

Keywords. Piedmont Zone; Ganga Plain; geomorphology; active tectonics; alluvial fans. 


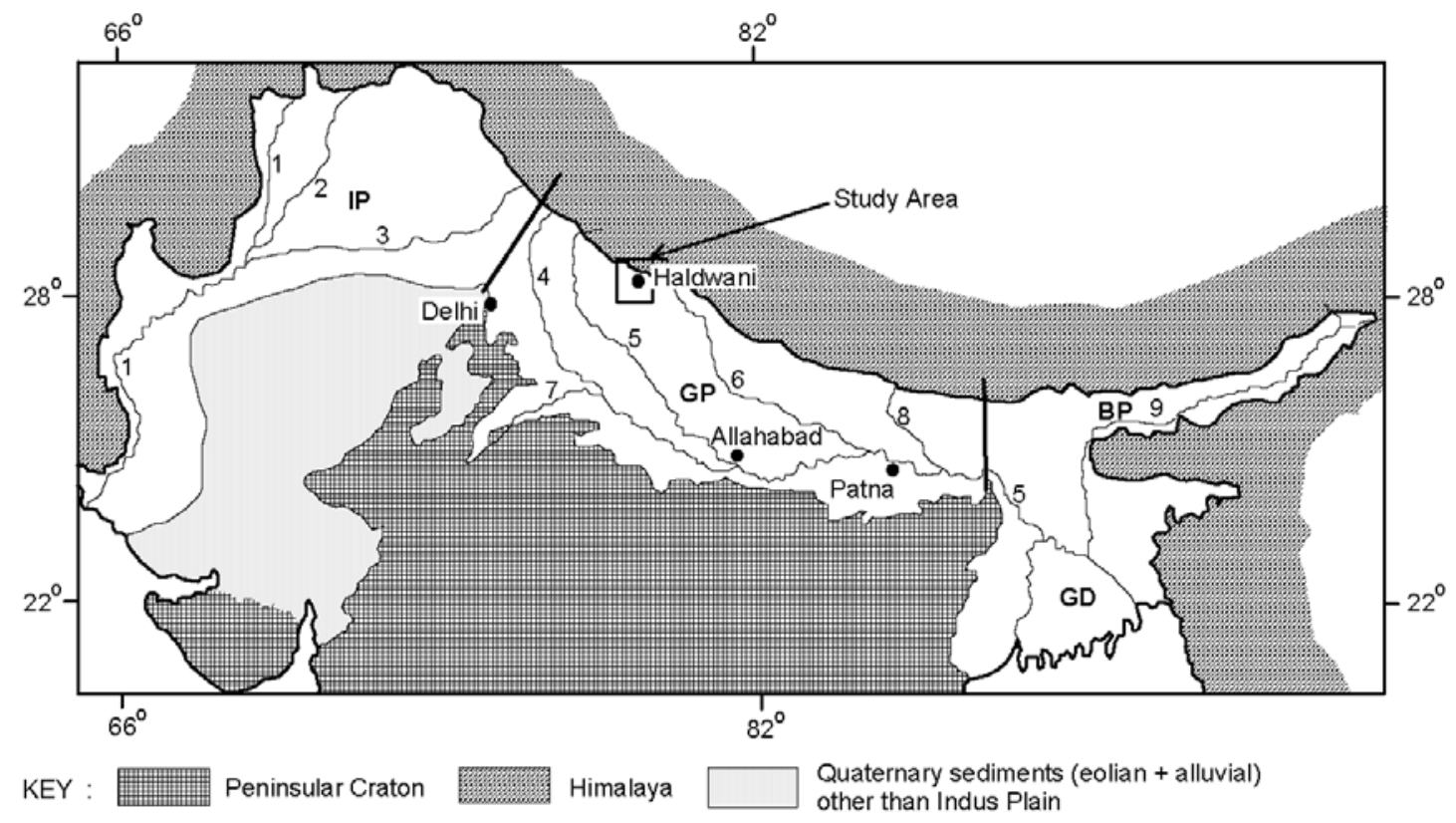

Figure 1. Extent of the Indo-Gangetic Plain between the Himalaya and the Peninsular Craton (after Singh 2004). Rectangle marks the location of the study area. IP: Indus Plain; GP: Ganga Plain; BP: Brahmaputra Plain; GD: Ganga Delta; 1. Indus River; 2. Jhelum River; 3. Sutluj River; 4. Yamuna River; 5. Ganga River; 6. Ghaghra River; 7. Chambal River; 8. Gandak River and 9. Brahmaputra River.

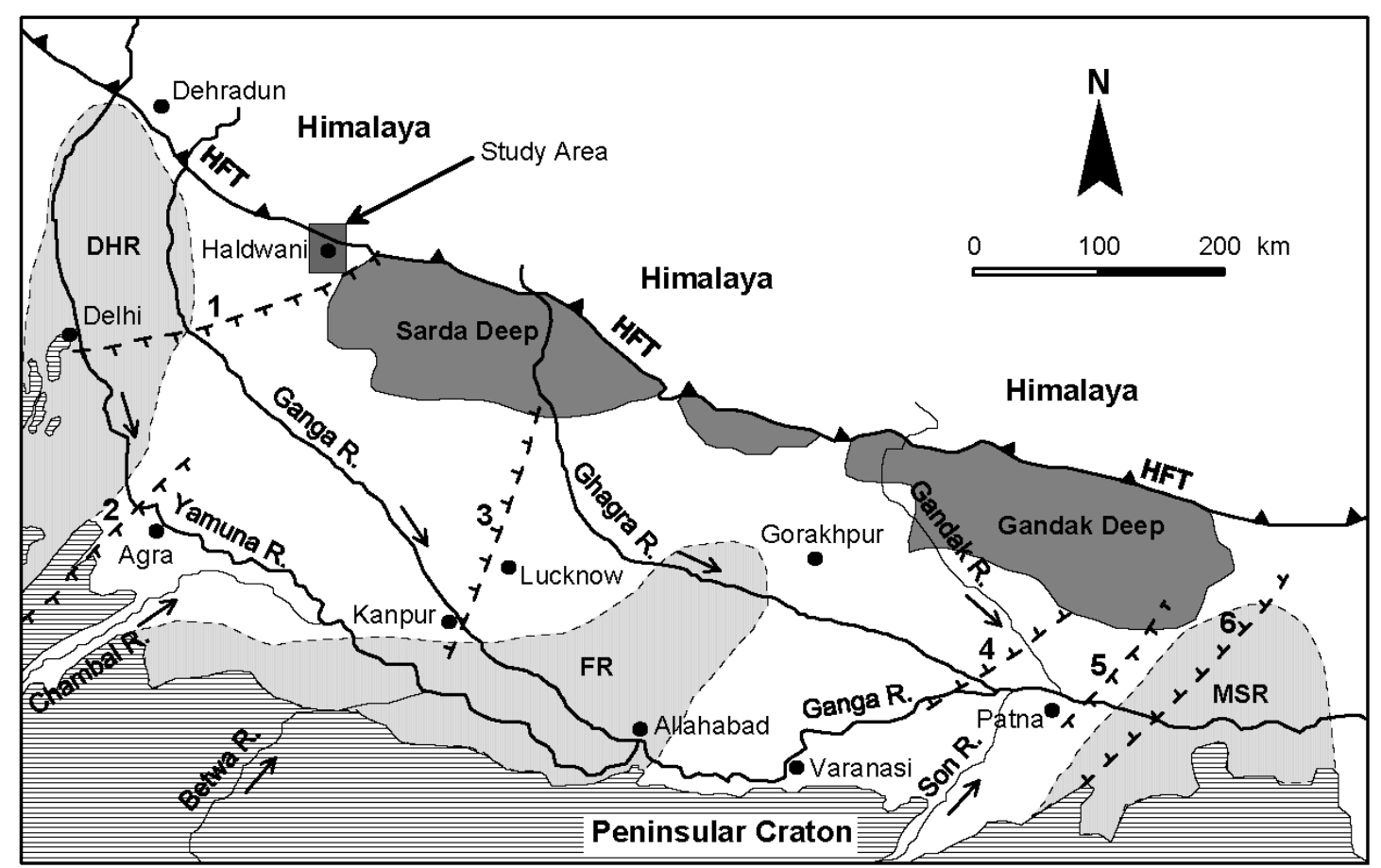

Figure 2. Map showing tectonic features of the basement of Ganga Basin (compiled from Sastri et al 1971; Rao 1973; Karunakaran and Ranga Rao 1979; Singh 2004; Sinha 2005). HFT: Himalayan Frontal Thrust; DHR: Delhi-Hardwar Ridge; FR: Faizabad Ridge; MSR: Monghyr-Saharsa Ridge; 1. Moradabad Fault; 2. Great Boundary Fault; 3. Lucknow Fault; 4. West Patna Fault; 5. East Patna Fault; 6. Monghyr-Saharsa Ridge Fault; R. River. Rectangle marks the location of the study area.

various fluvial processes. The major rivers of the Ganga Plain show development of broad valleys occupied by the River Valley Terrace Surface $\left(T_{1}\right)$, into which the active channel of the river is incised by a few meters. The $T_{1}$ surface is believed to have formed during late Late Pleistocene (35-25 ka) 


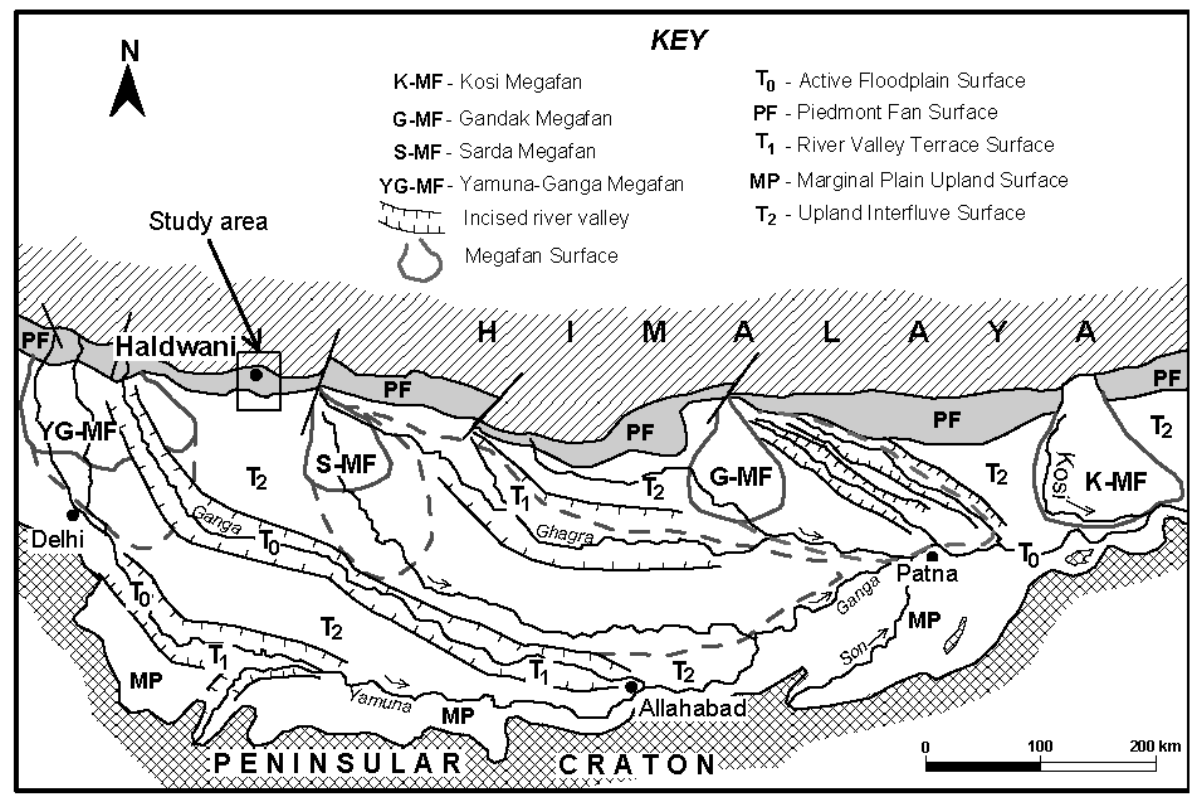

Figure 3. Map showing different geomorphic surfaces of the Ganga Plain (simplified after Singh 1996, 2004 and Shukla 2008). Rectangle marks the location of the study area.

and characterized by rippled and cross-bedded silt, sand and lensoid units of silty mud. Subsequent to the formation of $T_{1}$, the $\sim 10-50 \mathrm{~km}$ wide Piedmont Fan (PF) Surface (also called Piedmont Zone) formed adjacent to the Himalayan foot-hills during the latest Pleistocene $(25-10 \mathrm{ka})$ as a result of the coalescence of several gravelly alluvial fans during a regime of low rainfall and reduced sediment budget (Singh 2004). This surface is superimposed on the MF and $T_{2}$ surfaces, which are generally sandy in nature. The Active Floodplain Surface $\left(T_{0}\right)$ is the youngest geomorphic surface. It includes active river floodplains incised into the $T_{1}$ surface and interpreted to have formed in the past 10,000 years.

A great deal of work has been done over the past few years on various geological aspects of different geomorphic surfaces of the Ganga Plain (see Singh 1996, 2004; Sinha et al 2005; Tandon et al 2008 and references therein). Nevertheless, the Piedmont Zone still remains the least studied part; no information is available so far on the disposition of various landforms or the tectonic setting. The purpose of this paper is to fill this gap in knowledge about the Piedmont Zone and to evaluate the causes of geomorphic variations among alluvial fans of the area. We have studied a part of the Piedmont Zone in Kumaun region of the Uttarakhand state of India (figures 1 and 3) in terms of its morphotectonic setting with emphasis on morphology, surface characteristics and aggradation processes of alluvial fans. The alluvial fans of the Piedmont Zone are distinct from the megafans, which cover large areas in the northern and central parts of the Ganga Plain (Gohain and Parkash 1990; Mohindra et al 1992; Singh et al 1993; Shukla et al 2001). Moreover, the megafans are sandy in nature and devoid of debris flows (Shukla et al 2001), whereas the alluvial fans in the Piedmont Zone have formed by both fluvial and debris flow processes in multiple fan building cycles influenced by syn-depositional tectonic and climatic events (Shukla and Bora 2003; Shukla 2008).

\section{Geological setting and the study area}

The Ganga Plain is the central part of the alluvium filled Indo-Gangetic foreland basin system formed on the Indian Plate lithosphere which was flexed downward in response to the overriding of the Himalaya following collision of the Indian and Asian plates (Dewey and Bird 1970; Lyon-Caen and Molnar 1985). Geophysical surveys show that there are a number of ridges and basins in the metamorphic basement of the Ganga Basin (figure 2) (Sastri et al 1971; Rao 1973; Karunakaran and Ranga Rao 1979; Lyon-Caen and Molnar 1985). The important basement ridges are Delhi-Hardwar Ridge in the west, Faizabad Ridge in the middle and Monghyr-Saharsa Ridge in the east. The important basins are Sarda and Gandak deeps (figure 2). The entire Ganga Basin is traversed by a number of basement faults (1-6 in figure 2) (Sastri et al 1971; Rao 1973) some of which are extensions of the faults of the Peninsular India and extend into the Himalaya (Sastri et al 1971; Rao 1973; Valdiya 1976). 
The thickness of the sediment fill in the Ganga Basin, comprising Siwalik succession of the Upper Tertiary age and overlying Quaternary alluvium, is a maximum of $\sim 6 \mathrm{~km}$ in the Piedmont Zone and decreases gradually towards the south (Rao 1973). The northern limit of the basin is defined by the Himalayan Frontal Thrust (HFT), along which the Siwalik is thrust over the Ganga Basin alluvium (Nakata 1972; Karunakaran and Ranga Rao 1979). In much of the Ganga Plain the HFT is a blind thrust concealed under the gravels of the Piedmont Zone (Yeats and Lillie 1991). A number of studies have shown that the mountain-front in the area is affected by neotectonic activity (Nakata 1972, 1989; Valdiya et al 1992; Valdiya 2003; Goswami and Pant 2007, 2008, amongst others). Recent geomorphological investigations in the western part of the basin have shown that there are number of active faults trending parallel as well as transverse to the Himalayan strike (Parkash et al 2000; Thakur 2004) and the southern part of the Piedmont Zone is also uplifted along a fault, trending parallel to the Himalayan strike, south of the HFT (Thakur 2004).

In the study area, located between longitudes $79^{\circ} 15^{\prime}-79^{\circ} 45^{\prime} \mathrm{E}$ and latitudes $29^{\circ} 0^{\prime}-29^{\circ} 25^{\prime} \mathrm{N}$, a thick succession of fine-grained sandstone horizons interbedded with maroon and green mudstone and shale of the Lower Siwalik Subgroup, overlain by salt-and-pepper grey, medium-grained sandstone of the Middle Siwalik Subgroup, ranging in age from Early to Late Miocene (Pilgrim 1910; Tandon 1991), is thrust over the gravels of Piedmont Zone along the HFT (figure 4). At the contact, the rocks of the Siwalik are highly sheared and steeply $\left(65^{\circ}-90^{\circ}\right) \mathrm{NE}$ dipping. To the north, Neoproterozoic rocks of the Lesser Himalaya are thrust over the Siwalik succession along the Main Boundary Thrust (MBT).

In terms of the tectonic framework, the study area lies on the western margin of the Sarda Deep, which is delimited to the west from the RoorkeeMoradabad shelf by the NE-SW trending Moradabad Fault. The Sarda Deep gradually deepens towards the southeast (figure 2), with a maximum thickness of sediment fill (i.e., Siwalik + alluvium) of $\sim 4500 \mathrm{~m}$. To the east of the Morababad Fault, the sedimentary fill rests unconformably on the Precambrian Vindhyan Supergroup. To the west of Morababad Fault, basin fill directly overlies the Aravalli basement (Sastri et al 1971; Rao 1973).

\section{Materials and methods}

This study involved morphotectonic analysis of the area using common morphometric parameters. Identification and mapping of geomorphic and tectonic features in the field is generally obscured due to thick forest cover and anthropogenic modifications of the landscape, and the friable and easily reworkable nature of the unconsolidated gravels. Therefore, these investigations focus on analysis and interpretation of satellite imagery and Digital Terrain Models (DTMs) together with detailed fieldwork. Digital LISS III imagery, having a spatial resolution of $23.5 \mathrm{~m}$, from a pre- and a post-monsoon period (i.e., March 2004 and October 1997 respectively) from the Indian Remote Sensing Satellites (IRS) have been used for delineation and mapping of various morphotectonic features.

Georeferencing and, subsequently, enhancement of the satellite data such as contrast stretching, filtering, band ratioing, colour composite, etc., were accomplished with ERDAS IMAGINE software. The remote sensing images were georeferenced with the help of Survey of India toposheets (surveyed in 1964-65) on 1:50,000 scales. The Root Mean Square errors during georeferencing of March 2004 and October 1997 images were 0.512 and 0.497 respectively, which correspond respectively to 12 and $11.5 \mathrm{~m}$ on the ground. DTMs, like Digital Elevation Model (DEM), slope angle, slope aspect and 2-D cross-sections were prepared using ArcGIS Geographical Information System (GIS) from relief and drainage information provided in Survey of India toposheets. Elevation contours at $20 \mathrm{~m}$ and $100 \mathrm{~m}$ intervals have been drawn for the Piedmont and mountain areas respectively, in addition to all elevation points. Several hydrologically correct, grid-based DEMs were prepared for different resolutions $(25,50,100$ and $150 \mathrm{~m}$ grid sizes) using the TOPOGRID command in ArcGIS software. Several 3-D perspective views were generated by draping the satellite data over the DEMs, for different exaggeration factors (ranging from 1 to 25) of the $\mathrm{z}$-value, sun azimuth and sun angles. DTMs were then analyzed in conjunction with the digitally processed satellite imagery to delineate various morphotectonic features present in the area. Subsequently, the maps were verified during extensive field investigations, and required corrections were made by incorporating the field data.

The alluvial fan boundaries have been demarcated on the basis of morphological characters as proposed by Blair and McPherson (1994a). The morphological characters of alluvial fans, like shape, slope angle, slope aspect, longitudinal and transverse profiles, and drainage pattern were examined through DTMs prepared in a GIS. The morphological parameters of alluvial fans, like area, length, width, slope angle were calculated in GIS. The tectonic tilt of the fan was calculated following the methodology proposed Pinter and 


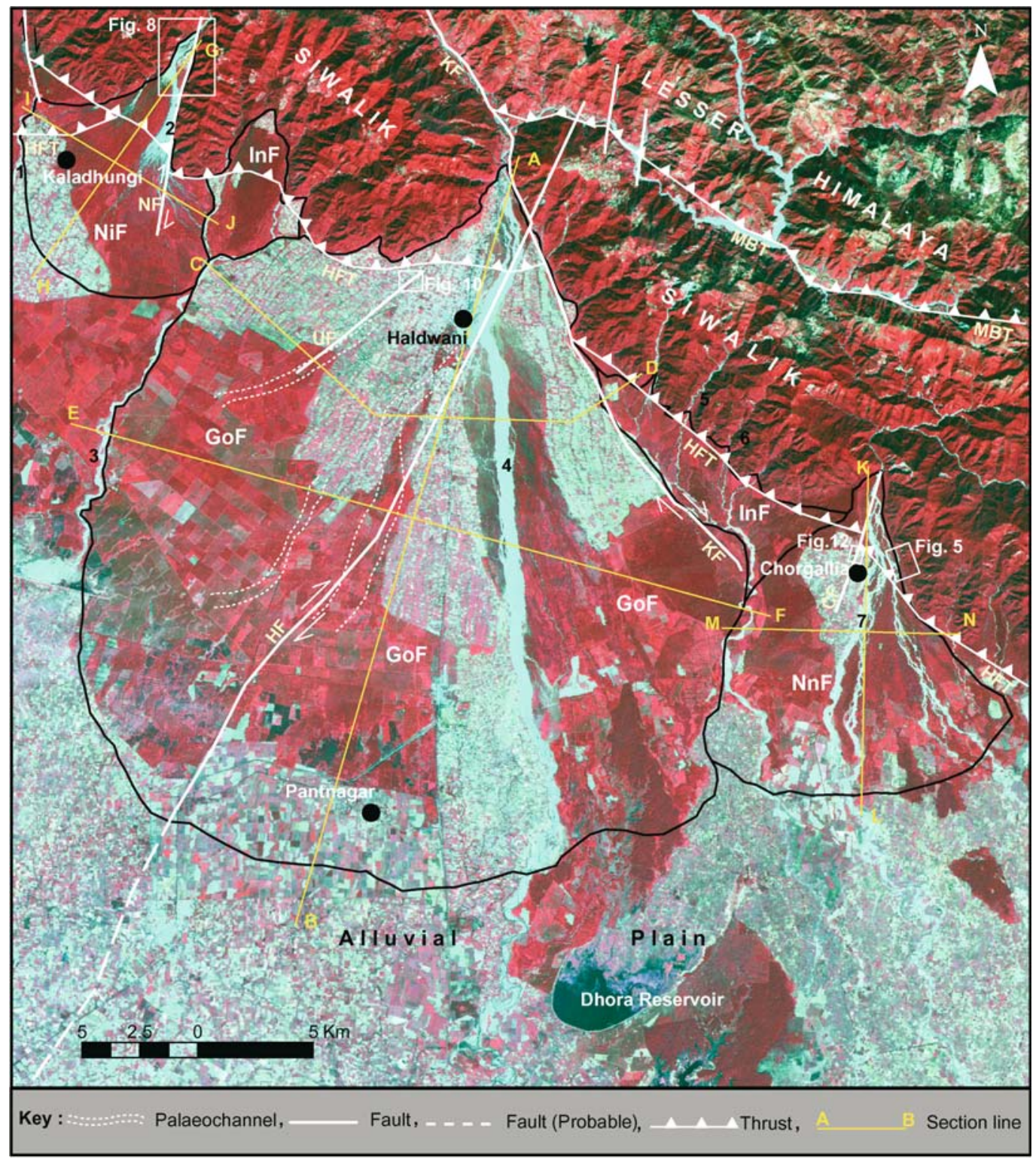

Figure 4. IRS LISS III False Colour Composite (Band 2, 3, 4) imagery of October 1997 of the study area showing various morphotectonic features in the Piedmont Zone. Lines AB to MN are sections along which topographic profiles shown in figures 7, 9 and 11 are drawn. White rectangles mark locations of corresponding figures. NiF: Nihal Fan; GoF: Gola Fan; NnF: Nandhaur Fan; MBT: Main Boundary Thrust; HFT: Himalayan Frontal Thrust; NF: Nihal Fault; UF: Unchapul Fault; HF: Haldwani Fault; KF: Kathgodam Fault; CF: Chorgallia Fault; 1. Baur River; 2. Nihal River; 3. Bhakra River; 4. Gola River; 5. Jam Gadhera; 6. Purjiya Nala; 7. Nandhaur River. Gadhera and Nala stand for streams.

Keller (1995). Measurements for all mathematical calculations were also performed in GIS.

\section{Morphotectonic setting of the study area}

The study area is located in a sub-tropical region. The mean annual temperature varies from $22^{\circ}$ to $26^{\circ} \mathrm{C}$, with a maximum of $\sim 40^{\circ} \mathrm{C}$ during daytime in summer and a minimum $\sim 7^{\circ} \mathrm{C}$ during winter nights. The rainfall in the area is influenced by the southwest monsoon, the Indian Summer Monsoon, with a maximum rainfall during July and August. Westerlies contribute $\sim 5-8 \%$ to the annual rainfall during the months of December to February. During the last decade, the average rainfall in the region has been $2076 \mathrm{~mm} /$ year with a maximum rainfall during the months of July and August varying between 590 and $600 \mathrm{~mm} /$ year (Shukla and Bora 2003).

A detailed morphotectonic map of the Piedmont Zone of the area has been prepared (figure 4) on the basis of remote sensing-, GIS- and field-based investigations. The Baur, Nihal, Bhakra, Gola (also called Gaula) and Nandhaur rivers and their 


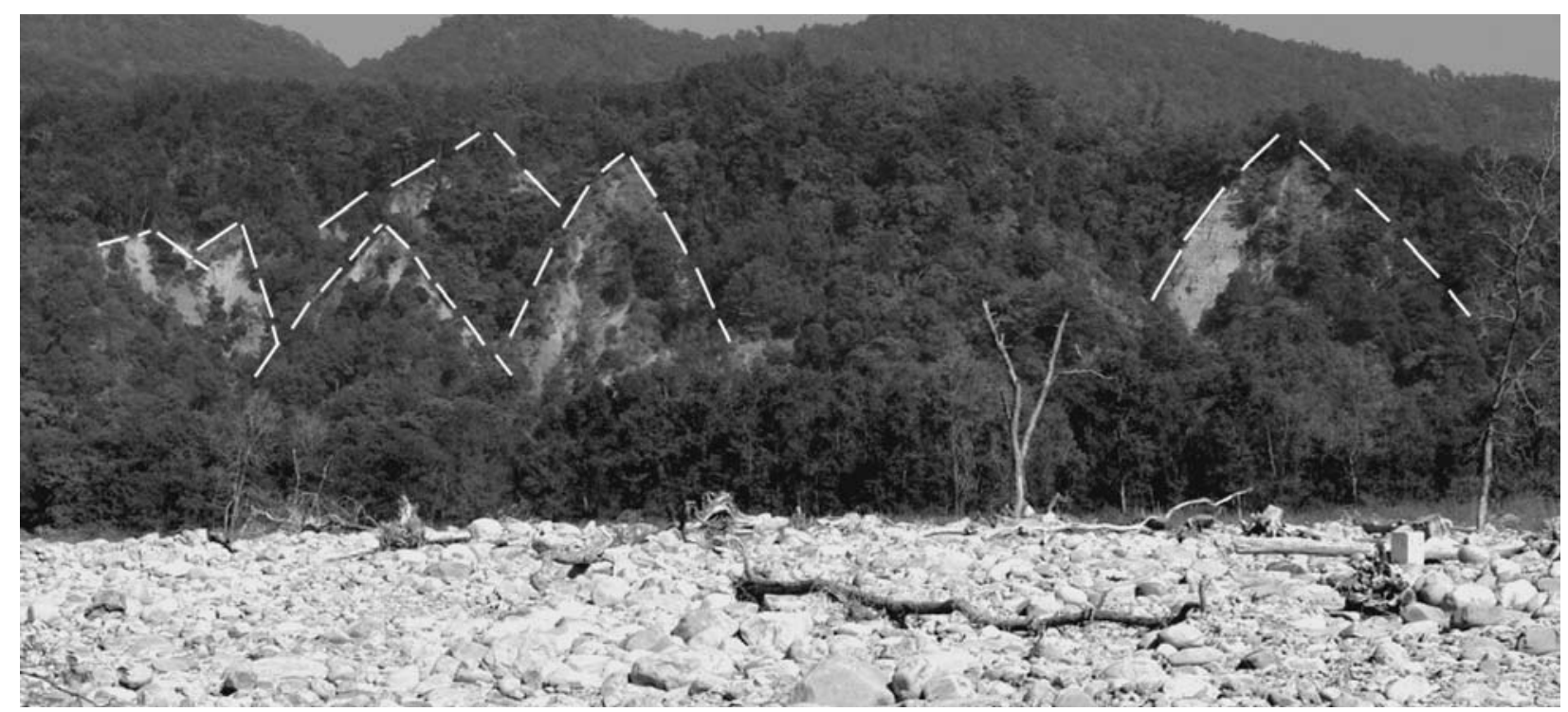

Figure 5. Photograph showing triangular fault-facets developed along the Siwalik mountain-front, east of Chorgallia. Gravels of Nandhaur River are seen in the foreground. Observer looks north-eastward.

tributary and distributary streams drain the area. The Nihal, Gola and Nandhaur rivers have formed distinct alluvial fans in the area. These have been delineated and named respectively as 'Nihal Fan', 'Gola Fan' and 'Nandhaur Fan'. Besides the main feeder channel, the fans also have a few seasonal feeder streams having subsidiary drainage basins in the mountain-front. The alluvial fans of the area are large, concave in longitudinal profile and convex in transverse profile and generally exhibit undulating surfaces. The expansion of sedimentary flows in the fan-head areas of the fans is between $30^{\circ}$ and $35^{\circ}$ as they are confined within mountainfront embayments formed by southward protruding Siwalik ridges. The inter-fan areas are occupied by talus and alluvial aprons of coalescent smaller fans having sediment inputs exclusively from the Siwalik Mountains.

\subsection{The mountain-front}

The Siwalik Mountains rise up to $\sim 1450 \mathrm{~m}$ amsl against the gently southward sloping Piedmont Zone. The latter extends up to $740 \mathrm{~m}$ amsl. The mountain-front exhibits a sub-parallel to subdendritic drainage pattern with characteristically deeply incised V-shaped valleys. The slope facets along the mountain-front generally are planar except for landslides and talus deposits, which are convex in the accumulation zones and concave in scarps. Triangular facets and cliffs are developed along different segments of the mountainfront (figure 5); cliffs in particular are developed along mountain-front embayments.

Mountain-front sinuosity $\left(S_{m f}\right)$ and valley-floor width to height ratios $\left(V_{f}\right)$, as defined by Bull
(1977, 1978) and Keller and Pinter (1996) have been calculated for the mountain-front. The combination of these two indices allows the inference of tectonic activity along the front-bounding fault (Silva et al 2003). The $S_{m f}$ is a measure of the degree of irregularity or sinuosity at the base of a topographic escarpment. It is defined as the ratio of the length of a segment of mountainfront $\left(L_{m f}\right)$ to the length of a straight line joining the ends of the same segment $\left(L_{s}\right)$ (mathematically, $\left.S_{m f}=L_{m f} / L_{s}\right)$. The $S_{m f}$ values in the study area, calculated along different segments of the mountain-front each having a distinct orientation, range between 1.01 and 1.61 (figure 6). The mountain-front adjoining the Gola Fan has relatively higher $S_{m f}$ values (1.06-1.61) compared to other segments (1.01-1.41).

The $V_{f}$ is mathematically expressed as:

$$
V_{f}=2 V_{f w} /\left[\left(E_{l d}-E_{s c}\right)+\left(E_{r d}-E_{s c}\right)\right]
$$

where $V_{f w}$ is the valley width, $E_{l d}$ is altitude of left bank, $E_{r d}$ is altitude of right bank and $E_{s c}$ is altitude of the channel. In the study area, $V_{f}$ values have been calculated for the Nihal, Gola, Jam Gadhera, Purjiya Nala and Nandhaur valleys at a set distance of $800 \mathrm{~m}$ from the mountain-front. The values are low, ranging between 0.22 and 0.78 for all valleys except the Gola River valley, which has a value of 1.23 .

\subsection{The Nihal Fan}

The Nihal Fan has an area of $\sim 61 \mathrm{~km}^{2}$ in the western part of the study area (figures 4, 7A and 7B). 


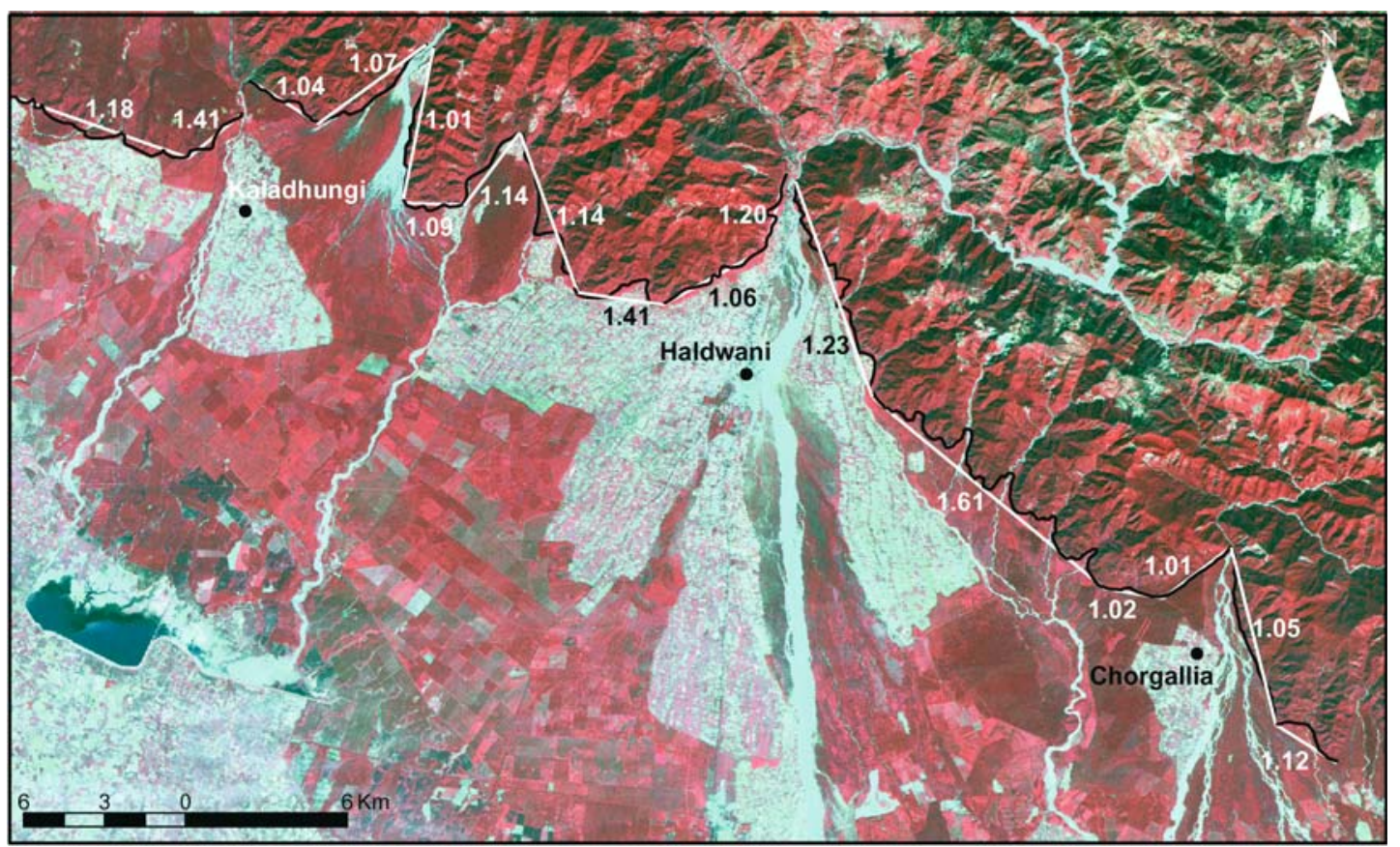

Figure 6. IRS LISS III False Colour Composite (Band 2, 3, 4) imagery showing mountain-front sinuosity ratios $\left(S_{m f}\right)$ for different segments of the Siwalik mountain-front.
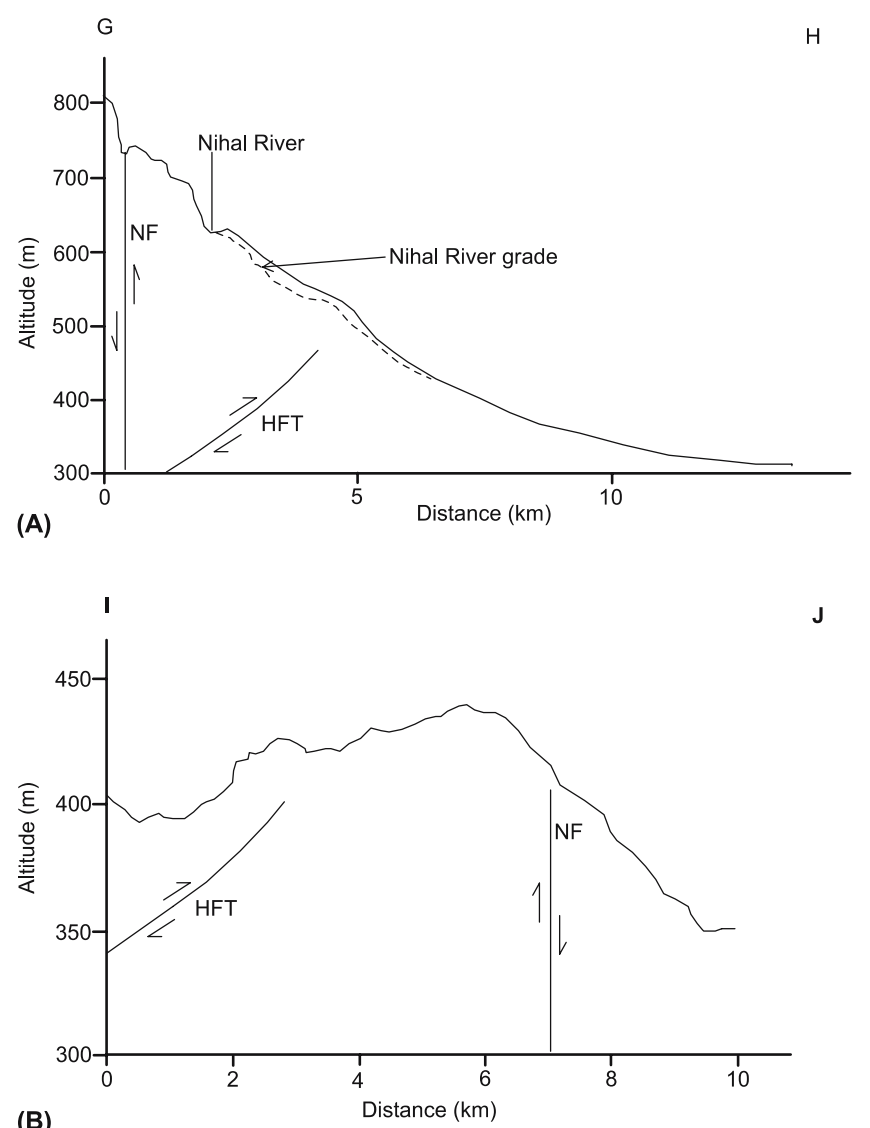

Figure 7. Topographic profiles of Nihal Fan along lines shown in figure 4 . The tectonic lines are drawn irrespective of dip measurements to highlight topographic expressions of tectonic movements. Abbreviations are same as used in figure 4 .
The flow expansion angle beyond the mountainfront embayment is $\sim 115^{\circ}$. The radial length of the fan is $\sim 12 \mathrm{~km}$, and the average radial slope is $\sim 3.08^{\circ}$ in SSE to SSW direction in the proximal part and $\sim 0.96^{\circ}$ in SE to SW direction in the distal part of the fan. The proximal part of the fan is uplifted $\sim 10 \mathrm{~m}$ along the HFT (figure $7 \mathrm{~A}$ ). The feeder channel has carved a deep gorge, but at the fan-head a channel bar and two levels of terraces along the left bank of the stream are developed. The average elevation differences between successive terraces from river bed are $\sim 4$ and $\sim 7.5 \mathrm{~m}$ respectively (figure 8). Upon leaving the fan-head, the bulk of the stream flow is transferred downfan by a stream flowing southward along the eastern margin of the fan; however, a few seasonal distributary streams radiate out from the main stream towards SE to SW. The main stream as such does not maintain a central position on the fan, but rather is shifted eastward. Further downfan, at a distance of $\sim 4.2 \mathrm{~km}$ from the fan apex, the intersection point is located with several distributary streams radiating in SE to SSW directions. The distributary streams ultimately join either the Baur River or Bhakra River flowing respectively along the western and eastern margins of the fan. The trend of the Nihal River in the drainage basin and on the fan is controlled by a NNE-SSW trending fault as manifested by the development of cliffs, triangular facets, terraces and landslides along its trace. This fault, called the Nihal Fault hereafter, has uplifted the western block as evidenced by the 


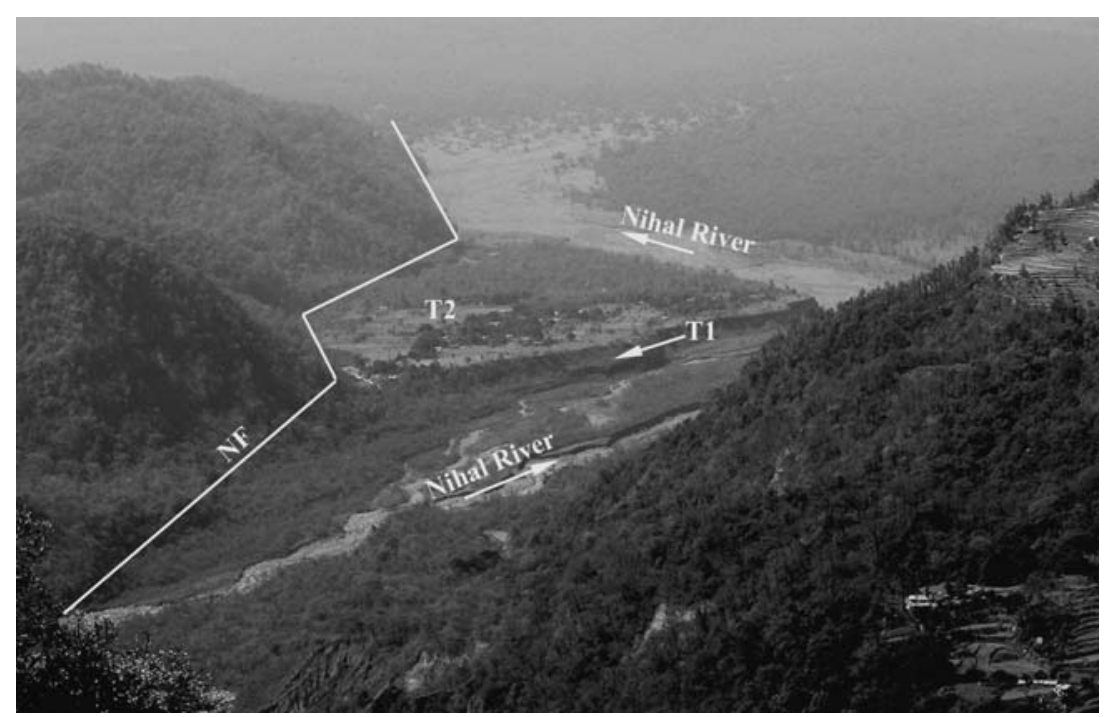

Figure 8. Photograph showing two levels of terraces developed along the right bank of Nihal River in the fan-head area of Nihal Fan. The observer looks southward. NF: Nihal Fault; T1 and T2: terraces.

development of unpaired terraces at the fan apex and caused eastward shifting of the axial river and depocentre.

The distributary streams shift frequently and deposit sediment on the fan mainly through sheetfloods. The sediment fill is composed of sheet to channelised, clast-supported and disorganised, matrix-supported gravels and a few sand horizons. The gravels are dominated by rounded to sub-rounded, pebble- to boulder-sized clasts of dolomite, marls, sandstone, siltstone and mudstone derived from the Lesser Himalayan and Siwalik Mountains. The drainage basin covers an area of $\sim 51 \mathrm{~km}^{2}$, wherein the Lesser Himalayan rocks are profusely fractured and joined owing to intense deformation in the MBT zone.

\subsection{The Gola Fan}

The Gola Fan is the largest of the three fans in the study area. It has an area of $\sim 631 \mathrm{~km}^{2}$, a radial length of $\sim 30 \mathrm{~km}$, and an average radial slope of $\sim 0.58^{\circ}$ in the SE to $\mathrm{SW}$ directions in the proximal part and $\sim 0.31^{\circ}$ in the SE to $\mathrm{W}$ directions in the distal part of the fan (figures 4,9A, 9B and 9C). The flow expansion angle beyond the mountainfront embayment is $\sim 132^{\circ}$. The transverse extent of the fan is limited to the west by the Bhakra River and to the east by the Sukhi Gad stream. The eastern boundary of the fan along the Sukhi Gad stream is almost straight as it is defined by the NNW-SSE trending fault against which the interfan gravels in the east abut. This fault is the southeastern extension of the Kathgodam Fault which coincides with the MBT in the northwest (Valdiya 1976). The entire flow across the fan is confined to a single channel that is incised up to $20 \mathrm{~m}$ in the proximal and up to $4 \mathrm{~m}$ in the distal part of the fan so that no distributary stream radiates from the main channel and the fan does not receive sheetflood sediments.

The fan surface shows two prominent linear bulges up to $2 \mathrm{~m}$ high. One of these, trending nearly $\mathrm{E}-\mathrm{W}$, is in the proximal part of the fan whereas the other, trending nearly NNE-SSW, extends all along the fan surface (figures 9A and 9B). These bulges may represent upwarping related to movements along faults concealed below the alluvium; the former may be related to an E-W trending segment of the HFT and the latter to a NNE-SSW trending fault, called the Haldwani Fault hereafter. The presence of a NNE-SSW trending palaeochannel downstream of Haldwani, in line with the active channel upstream, suggests that movements along this fault have caused uplift of the western fault block so that the Gola River has shifted eastward following an avulsion just downstream of Haldwani (figure 4). A comparison of the toposheet (surveyed in 1964-65) with the satellite data of 1997 and 2004 reveals that, over the period of last forty years, the width of river channel in the fan head area has increased from $\sim 522 \mathrm{~m}$ to $\sim 632 \mathrm{~m}$ as a result of lateral-cutting, and has shifted up to $360 \mathrm{~m}$ eastward. This may also be due to the uplift of right bank of the river along the Haldwani Fault. To the north of the fan, in the Siwalik Mountains this fault is expressed by a series of landslides and deflections in small streams draining the mountain-front. A large landslide near the village of Amiya on the northern slope of Siwalik is also located on the trace of this fault. To the west of and roughly parallel to this fault, another fault is developed which 


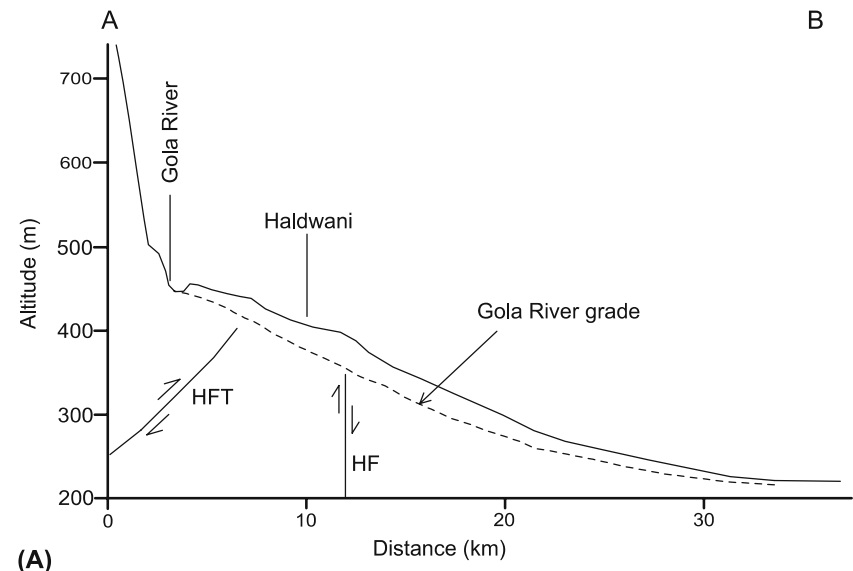

(A)

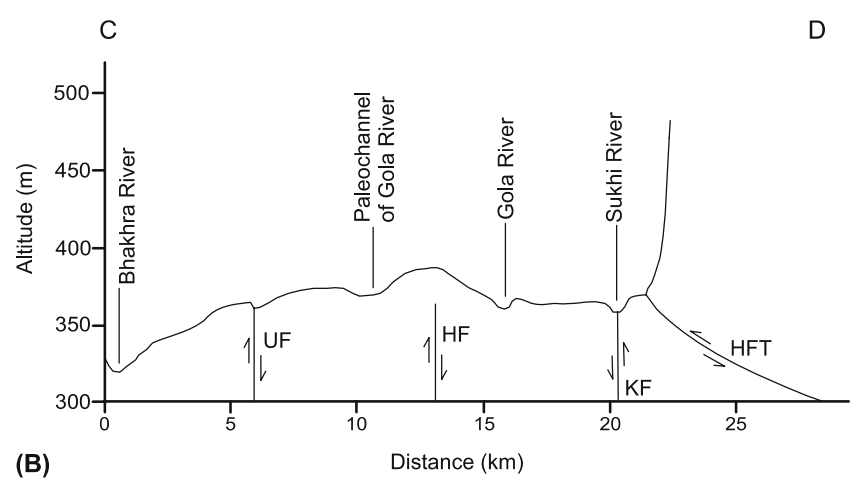

(B)

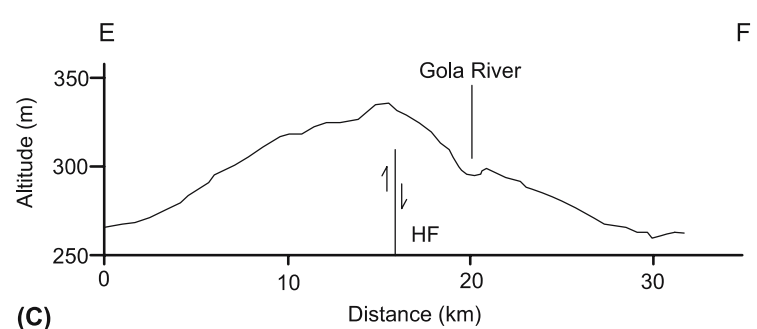

Figure 9. Topographic profiles of Gola Fan along lines shown in figure 4 . The tectonic lines are drawn irrespective of dip measurements to highlight topographic expressions of tectonic movements. Abbreviations are same as used in figure 4 .

has uplifted the western fault block up to $15 \mathrm{~m}$ (figure 10). Passing through the Unchapul locality of Haldwani, the scarp of this fault, called the Unchapul Fault hereafter, extends for a length of $\sim 6 \mathrm{~km}$.

The sediment fill of the Gola Fan consists of lensoid, clast-supported gravels and disorganised to sheet-like matrix-supported gravels with a few sand and fine clayey silty-sand horizons in the proximal part, and dominantly sandy and silty horizons with thin gravel horizons in the distal part. The clasts in the gravels are sub-rounded to wellrounded pebbles to boulders, mainly of sandstone, dolomite, marls, diamictite, silty shale, siltstone, mudstone, granite, vesicular basalt, mica schist and gneiss belonging to the Lesser Himalayan and
Siwalik succession. The drainage basin has an area of $\sim 146 \mathrm{~km}^{2}$ with $>80 \%$ of it extending into the Lesser Himalaya which have intensely fractured and joined rocks along the MBT and other fault zones.

\subsection{The Nandhaur Fan}

The Nandhaur Fan has a radial length of $\sim 14.5 \mathrm{~km}$ and covers an area of $\sim 107 \mathrm{~km}^{2}$ in the eastern part of the study area (figures 4, 11A and 11B). The average radial slope of the fan surface is $\sim 2.24^{\circ}$ towards the $\mathrm{S}$ in the proximal part and $\sim 0.30^{\circ}$ towards the SE to SW in the distal part of the fan. The flow expansion angle is $\sim 70^{\circ}$ beyond the mountain-front embayment. The feeder channel has carved a narrow gorge, but on the fan surface the intersection point lies very close to the fan apex. The distributary streams radiate in SSW to SE directions, shift frequently and cause sediment deposition on the fan surface mainly through sheetfloods. Some tributary channels descending from the Siwalik Mountain also join these distributary streams on the fan surface. The main stream maintains the central position on the fan surface.

The proximal part of the fan exhibits a prominent, up to $60 \mathrm{~m}$ high, NW-SE trending ridge composed of gravels, possibly formed as a result of upwarping related to movements along the HFT concealed below the alluvium. The fan surface in the proximal part is traversed by a fault passing through the Chorgallia market. This fault, called Chorgallia Fault hereafter, trending nearly NNESSW has uplifted the western fault block up to $\sim 8 \mathrm{~m}$ (figure 12). The scarp of the Chorgallia Fault extends for a length of $\sim 3 \mathrm{~km}$.

The sediment fill of the fan is composed of lensoid, clast-supported gravels, disorganised to sheet-like matrix-supported gravels and a few thin sand and silty-mud horizons. The clasts in gravels are sub-rounded to well-rounded, pebble- to boulder-sized, and composed of sandstone, silty shale, siltstone, mudstone, granite, vesicular basalt, mica schist with some diamictite and dolomite, all belonging to the Lesser Himalayan and Siwalik succession. The drainage basin of the fan covers an area of $\sim 95 \mathrm{~km}^{2}$ with a large part extending into the Lesser Himalaya. As in the drainage basins of other two fans, the rocks in the drainage basin are intensely deformed along the MBT and other fault zones. There are a number of landslides in the drainage basin.

\subsection{Tilting of the Gola Fan}

Keeping in view the tectonic framework, it is likely that the alluvial fans of the area are tilted. Therefore, to test this possibility a morphometric 


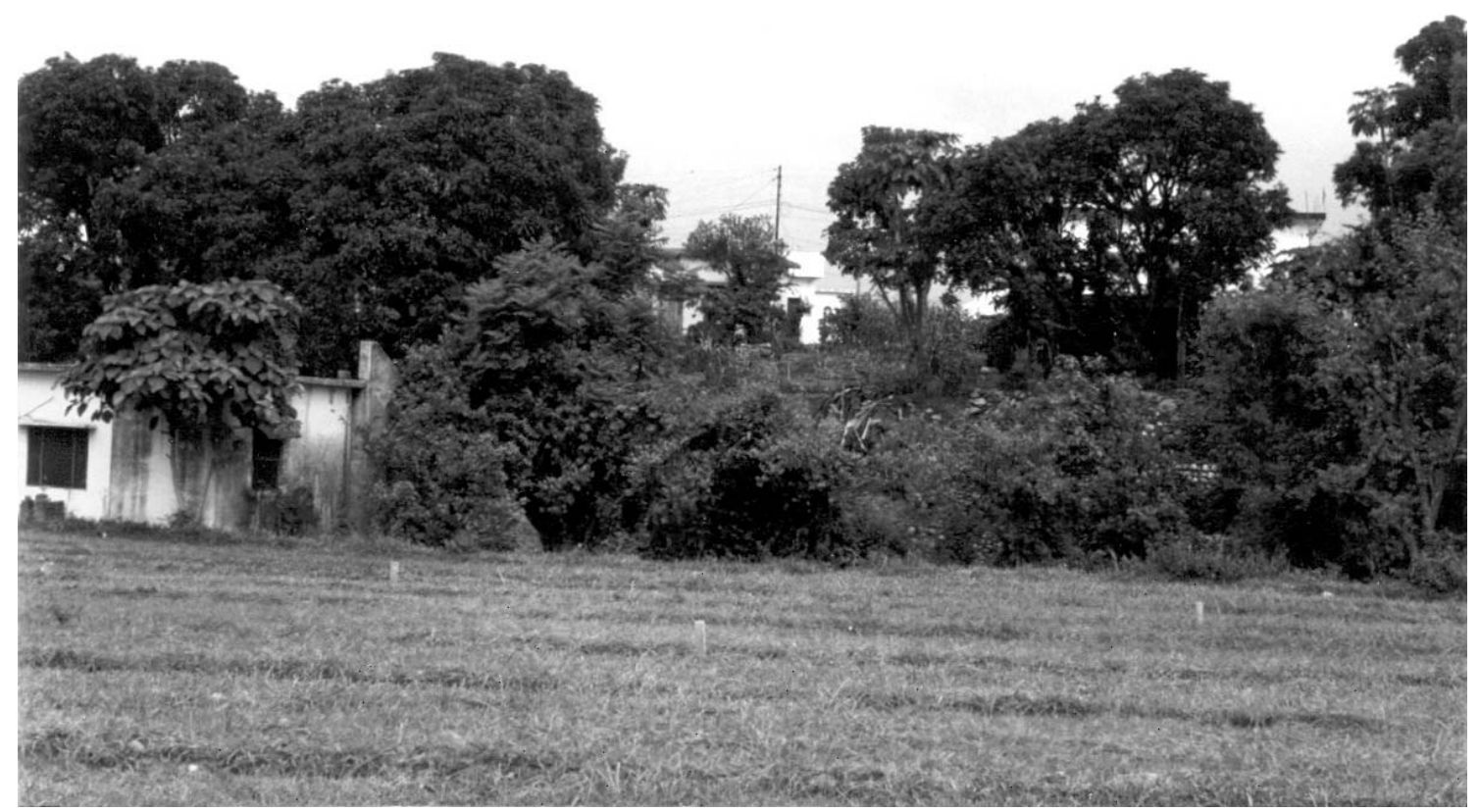

Figure 10. The scarp of Unchapul Fault in western outskirts of the Haldwani town. The observer looks westward.

technique developed by Pinter and Keller (1995) has been applied. The basic principle behind this technique is that, in the absence of tilting an alluvial fan can be described as a symmetrical half-cone with topographic contours on the surface defining concentric semicircles. But in case of tilting, the contours on the surface will represent segments of ellipses with their long axes oriented parallel to the direction of tilting (Pinter and Keller 1995). This methodology assumes that the surface of the fan has not experienced significant deposition since tilting started, because active deposition will continually anneal the fan and restore its concentric, untilted conical geometry (Burbank and Anderson 2001).

The angle of tilt of the fan $(\beta)$ can be calculated using the following equation:

$$
\left.\beta=\arccos \left[\sqrt{ }\left(\frac{b}{a}\right)^{2} \sin ^{2} \alpha+\cos ^{2} \alpha\right\}\right],
$$

where $\alpha$ is the original depositional slope, which is derived by measuring the slope along the minor axis of the ellipse, $b$ is the half of the length of the minor axis of the ellipse, and $a$ is the half of the length of the major axis of the ellipse.

In the study area, the Gola Fan, having no distributary channels is considered suitable for this analysis, whereas the Nihal and Nandhaur fans have not been taken up for these investigations as the sedimentation on these fan surfaces is currently active.
The original depositional slope of the Gola Fan is $1.19^{\circ}$. The lengths of major and minor axes of the resulting best-fitting ellipse are $\sim 26.792$ and $\sim 26.177 \mathrm{~km}$ respectively. Substituting these values in the above equation, the tilt in the Gola Fan is calculated to $0.36^{\circ}$ in SSE direction (figure 13).

\section{Discussion}

The alluvial fans of the area have different morphological characters as well as aggradation processes. The Gola Fan is the largest and gentlest while the Nihal Fan is the smallest and steepest. Axial rivers of both these fans are shifted towards the east rather than maintaining a course down the axis. The Nihal and Nandhaur fans are aggrading mainly through sheetfloods caused by distributary streams, whereas the river on Gola Fan is incised up to the distal part and contributes only channel lag sediments to the fan.

The geomorphic evolution of alluvial fans is controlled by catchment characteristics (including drainage basin area, relief and geology), tectonics and climate (Harvey et al 2005). The catchment characteristics influence mainly the size and slope of alluvial fans (Bull 1962; Hooke 1968; Hooke and Rohrer 1977). In conceptual models of fan evolution, the roles and relative importance of tectonics and climate are considered to be primary variables (Ritter et al 1995). Tectonics mainly influences the fan morphology by controlling the accommodation space (Silva et al 1992; Ferrill et al 1996; Calvache et al 1997; Viseras et al 2003) whereas climatic factors predominantly control the fan morphology and 

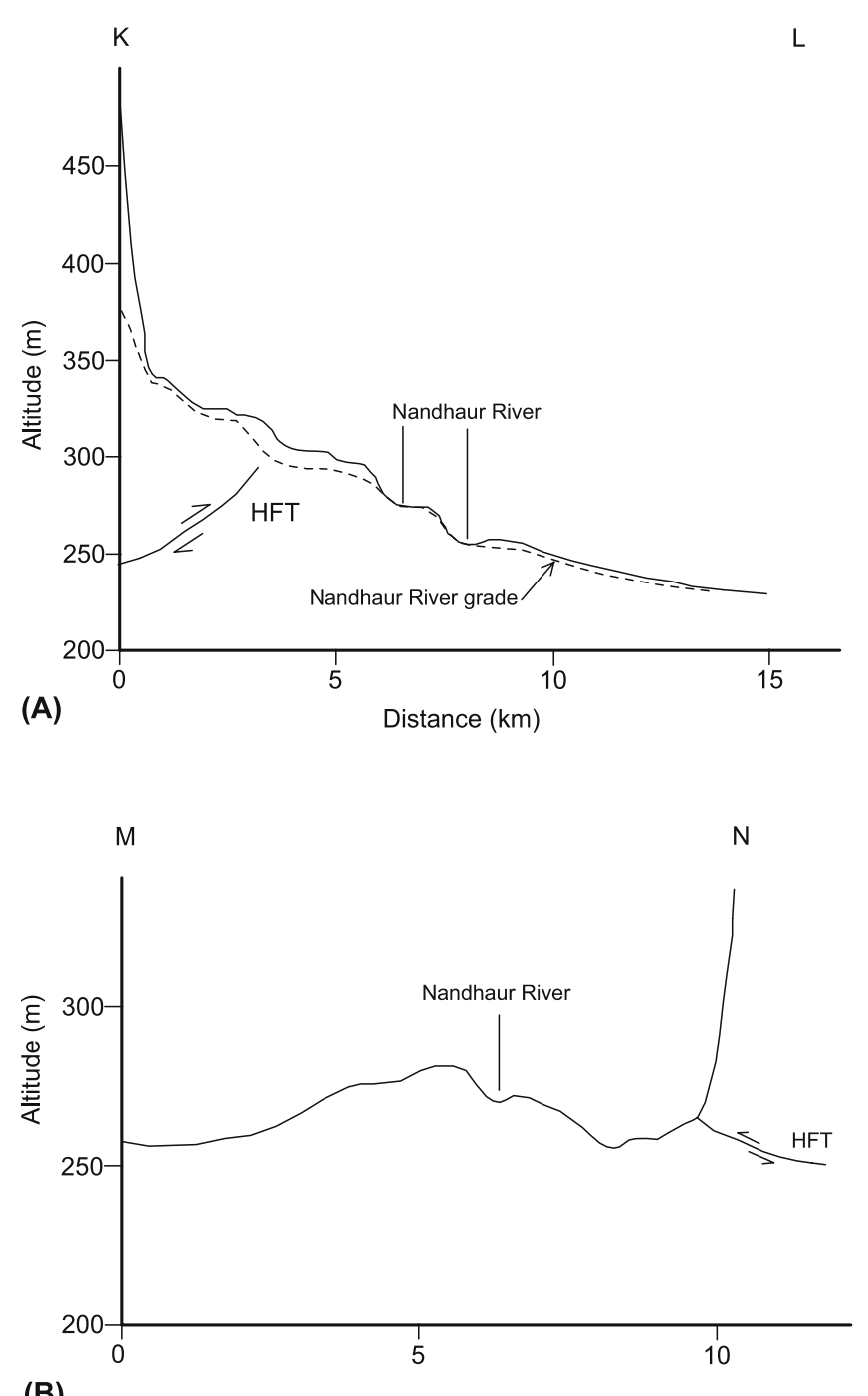

(B)

Distance $(\mathrm{km})$

Figure 11. Topographic profiles of Nandhaur Fan along lines shown in figure 4 . The tectonic lines are drawn irrespective of dip measurements to highlight topographic expressions of tectonic movements. Abbreviations are same as used in figure 4.

sedimentary styles (Harvey et al 2005). Moreover, studies that have evaluated the relative roles of tectonics and climate on Quaternary fans, demonstrate that climate is the primary control (Frostick and Reid 1989; Ritter et al 1995; Harvey 2004).

In the present case, however, the alluvial fans and their drainage basins are located in the same climatic zone and cover a relatively small geographic area. Further, the drainage basins for all the three alluvial fans have similar physiographic and litho-tectonic settings. Therefore, the geomorphic variations among these three alluvial fans are most plausibly controlled by tectonics and drainage basin dimensions. Singh and Tandon (2006) have also demonstrated that in frontal Himalaya the alluvial fan morphology is predominantly controlled by the tectonics. However, the individual fan exhibits temporal variations in sedimentary processes under the influence of Quaternary climatic events (Shukla 2008). The dimensions of the drainage basins are different for all the three fans of the study area and, conforming to Bull's (1962) results, are proportional to the area of fans. The slopes of the alluvial fans, on the other hand, are inversely proportional to their size and drainage basin area; the Nihal Fan is the steepest and Gola Fan is the gentlest. This is consistent with observations made by many workers (e.g., Bull 1964; Melton 1965; Blair and McPherson 1994b). Nevertheless, Gordon and Heller (1993), Calvache et al (1997) and Viseras et al (2003) have proposed that high subsidence rates along a basin margin favours vertical aggradation and smaller fans, whereas where subsidence is slow fans prograde basinward and become larger.

As mentioned earlier, while the Nihal and Nandhaur fans are aggrading mainly through sheetfloods in distributary streams, the sediments in Gola Fan are being deposited only in incised river as lag deposits, even though the climatic and physiographic conditions are similar. Sediment accumulation on fans takes place only if the accommodation space is available. This space is commonly driven by subsidence, uplift or eustatic sea-level change (Viseras et al 2003). However, in the present case, the role of eustatic sea level can be neglected as the study area is located hundreds of kilometres upstream of the area influenced by the sea-level rise or fall during the late Quaternary (Tandon et al 2006).

Subsidence and uplift related to movements along various faults strongly influence landforms in the area. Such movements bring forth spatially variable and temporally climate independent baselevel changes (Harvey 2002) leading to aggradation or dissection of the fans. The HFT defines the boundary between the Himalaya and the Ganga Plain, but in some segments, is concealed below the alluvium (Nakata 1972; Karunakaran and Ranga Rao 1979) such that some part of an alluvial fan lies on the hanging wall and the rest on the footwall of the thrust. Movements along the HFT have uplifted the proximal part of the fan leading to incision of rivers as well as development of low-relief alluvial ridges in the proximal parts of the Gola and Nandhaur fans. Singh (1996) also considers the presence of such small alluvial ridges as indicators of blind thrusts. The low values of $S_{m f}$ and $V_{f}$ along Siwalik mountain-front, also indicate the active nature of the HFT and of transverse faults of the area. The low values of $S_{m f}$ (close to 1) indicate relatively straight mountain-fronts associated with active tectonics and uplift (Keller and Pinter 1996). Bull and McFadden (1977) have concluded 


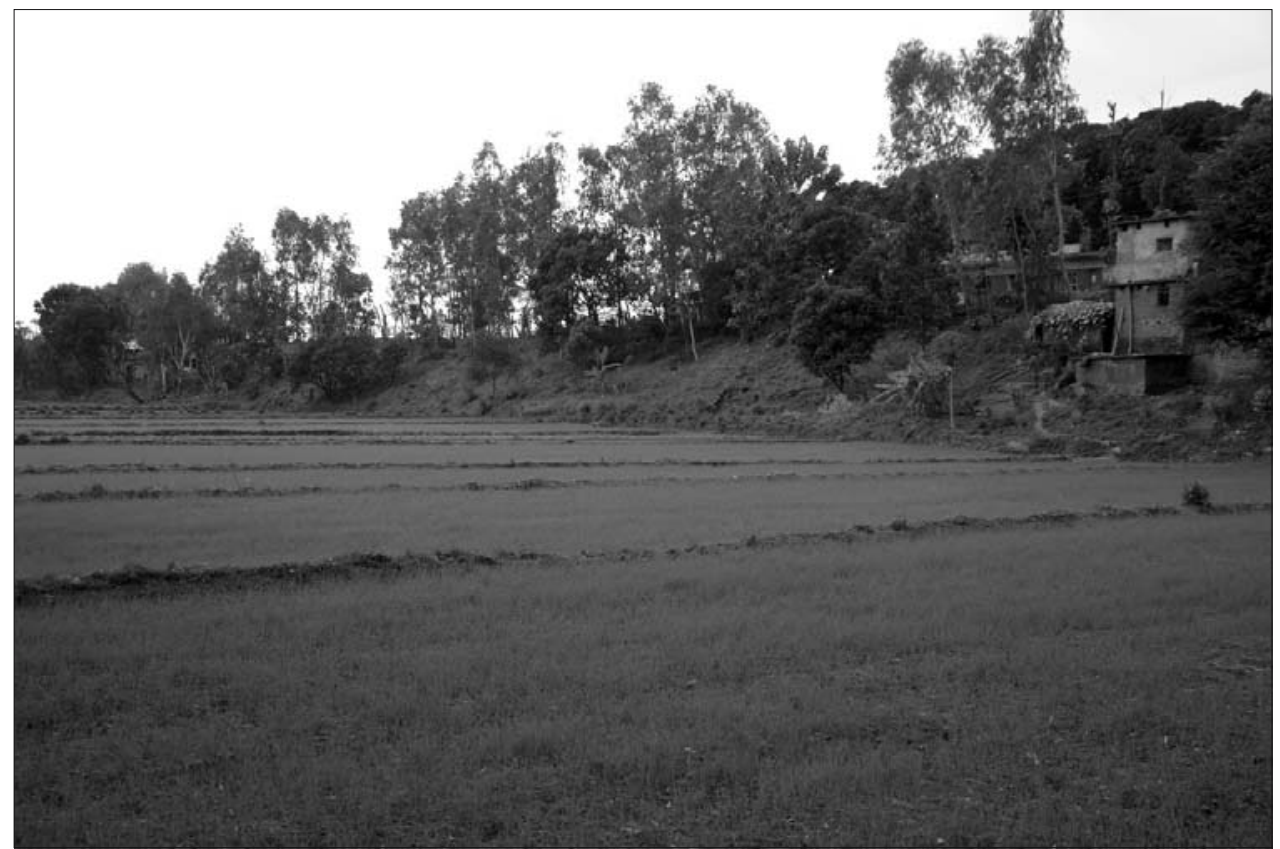

Figure 12. The scarp of the Chorgallia Fault developed to the north of the Chorgallia market. The observer looks south-westward.

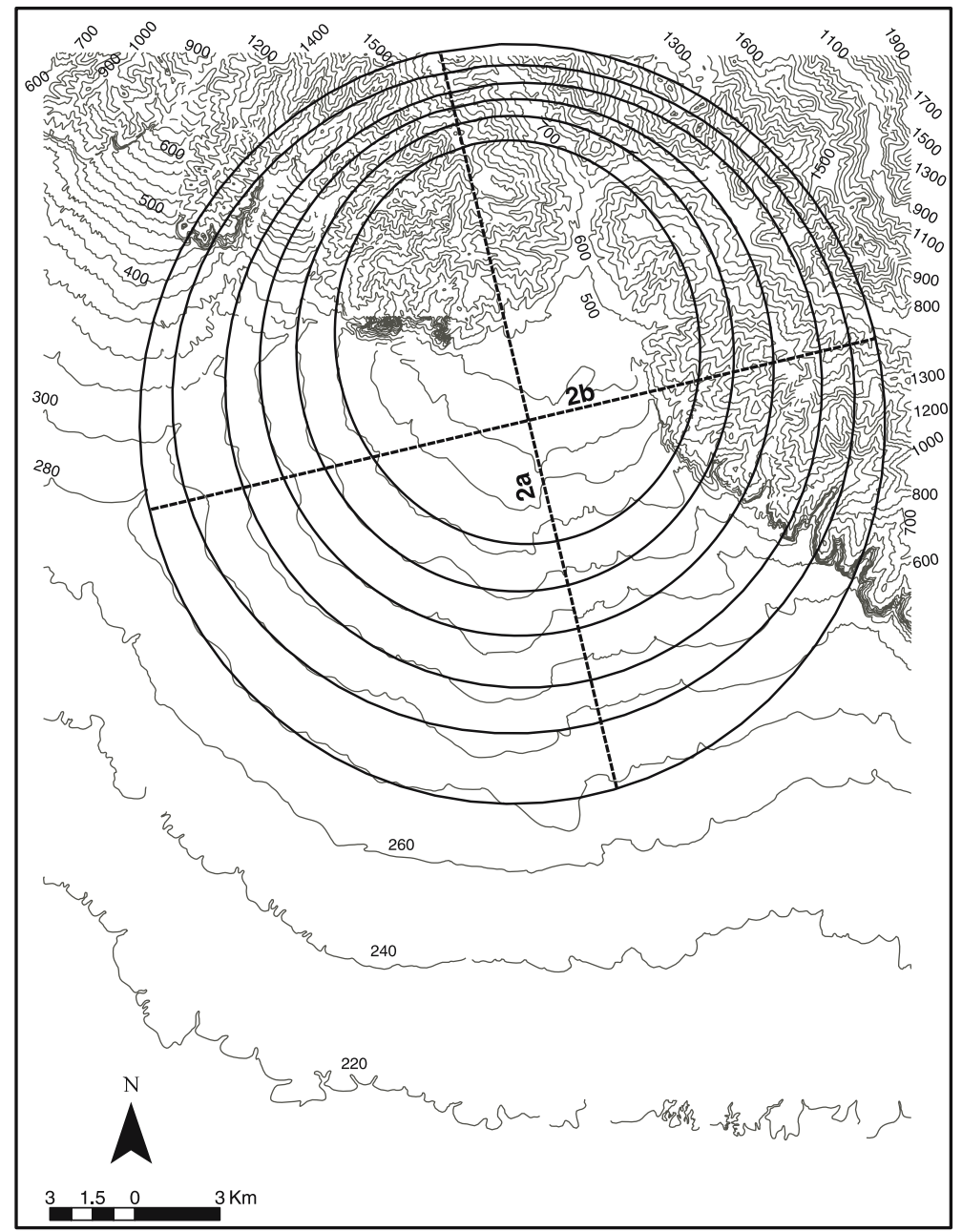

Figure 13. Diagram showing best-fit ellipses on elevation contours of the Gola Fan, for the calculation of tectonic tilt of the fan. $2 \mathrm{a}$ and $2 \mathrm{~b}$ are the major and minor axes of the ellipse respectively. 
that most active mountain-fronts have $S_{m f}$ values between 1.0 and 1.6, whereas less active and inactive mountain-fronts have $S_{m f}$ values between 1.4-3.0, and $>3.0$, respectively. Similarly, Silva et al (2003) suggested that values of $V_{f}<1.0$ are associated with the $\mathrm{V}$-shaped valleys developed in response to active uplift whereas values of $V_{f}>1.0$ are associated with broad U-shaped valleys, indicating major lateral erosion due to the stability of base level or tectonic quiescence. The higher $V_{f}$ value of the Gola River valley compared to low $V_{f}$ values of the other four river valleys of the area and the relatively higher $S_{m f}$ values of the associated mountain-front segments (1.06 to 1.61, in contrast to 1.01 to 1.41 elsewhere) are considered to indicate relatively less tectonic activity in this part of the study area. The low $S_{m f}$ values and development of cliffs along mountain-front embayments in the area indicate that their formation is controlled largely by tectonic activities, rather than erosion.

The tilting of the Gola Fan towards the SSE indicates uplift of its NNW part. This may be related to the uplift of the proximal part of the fan along HFT and oblique movements along the Haldwani, Unchapul and Nihal faults, all of which have upthrown western fault blocks. The presence of a NE-SW trending palaeochannel on the fan surface to the south of Haldwani, in line with the active incised channel upstream, indicates the avulsion of the Gola River in response to upwarping of the area as a result of movements on the Haldwani Fault. The incision of the Gola River is also a result of this upwarping. The movements along the Nihal and Haldwani faults have also caused eastward shifting of the axial river in Nihal and Gola fans respectively. Singh (2004) also attributed the incised river channels, warping and linear ridges in the Piedmont Zone to tectonic activity. Interestingly, the Kathgodam Fault along the eastern margin of the fan has prevented the progradation of interfan sediments on the eastern fault block; as such the area of Gola Fan between the Haldwani and Kathgodam faults is subsiding.

\section{Conclusions}

The present study has provided a detailed morphotectonic map of a part of the Piedmont Zone of the Ganga Plain. The area comprises alluvial fans, alluvial plains and interfan areas composed of alluvial aprons and talus deposits. The HFT and transverse faults in the area are tectonically active and have controlled the fan morphologies and sedimentary processes. The morphological variations among fans are related to the extent of basin subsidence caused by tectonic movements and drainage basin areas of the fans. The transverse faults have a strong influence on fan dissection and aggradation. The movements along transverse faults have caused shifting of the axial rivers of Nihal and Gola fans as well as the depocentre in case of the former. The Gola Fan has tilted towards SSE and the river incised into it because of movements along HFT and transverse faults.

\section{Acknowledgements}

The financial assistance from DST, New Delhi (vide research project SR/S4/ES-131/2005) is thankfully acknowledged. Facilities generated under UGC, SAP III and DST, FIST programmes are also fruitfully utilized. We are thankful to Roger LeB Hook, University of Maine, Orono, USA for critical review of an earlier draft of the manuscript, which resulted in significant improvements in the quality of the paper. We have been benefited through discussion with Prof. K S Valdiya, Bangalore and Prof. D C Srivastava, Roorkee. Constructive comments and suggestions from two anonymous reviewers have been very useful in improving the quality of the manuscript.

\section{References}

Blair T C and McPherson J G 1994a Alluvial fans and their natural distinction from rivers based on morphology, hydraulic processes, sedimentary processes, and facies assemblages; J. Sed. Res. A64(3) 450-489.

Blair T C and McPherson J G 1994b Alluvial fan processes and forms; In: Geomorphology of Desert Environments (eds) Abrahams A D and Parsons A J (London: Chapman and Hall) pp. 354-402.

Bull W B 1962 Relations of alluvial fan size and slope to drainage basin size and lithology in western Fresno County, CA; U.S. Geol. Surv. Professional Paper 450-B $51-53$.

Bull W B 1964 Geomorphology of segmented alluvial fans in western Fresno County, CA; U.S. Geol. Surv. Professional Paper 352-E 89-129.

Bull W B 1977 Tectonic geomorphology of the Mojave Desert: Menlo Park, California; U.S. Geol. Surv. Office of Earthquakes, Volcanoes, and Engineering, Contract Report 14-08-001-G-394, 188 p.

Bull W B 1978 Geomorphic tectonic activitiy classes of the south front of the SanGabriel Mountains, California: Menlo Park, California; U.S. Geol. Surv. Office of Earthquakes, Volcanoes, and Engineering, Contract Report 14-08-001-G-394, $59 \mathrm{p}$.

Bull W B and McFadden L D 1977 Tectonic geomorphology north and south of the Garlock Fault, California; In: Geomorphology in Arid Regions (ed.) Doehring D O (Binghamton, NY: State University of New York) pp. $115-138$.

Burbank D W and Anderson R S 2001 Tectonic Geomorphology (Massachusetts: Blackwell Science) 274 p.

Calvache M L, Viseras C and Fernández J 1997 Controls on fan development - evidence from fan morphometry and sedimentology; Sierra Nevada, SE Spain; Geomorphology 21 60-84. 
Dewey J F and Bird J M 1970 Mountain belts and new global tectonics; J. Geophys. Res. 40 695-707.

Ferrill D A, Stakamatos J A, Jones S M, Rahe B, McKague H L, Martin R H and Morris A P 1996 Quaternary slip history of the Bare Mountain fault (Nevada) from the morphology and distribution of alluvial fan deposits; Geology 24 559-562.

Frostick L E and Reid I 1989 Climatic versus tectonic controls of fan sequences: lessons from the Dead Sea, Israel; J. Geol. Soc. London 146 527-538.

Gohain K and Parkash B 1990 Morphology of the Kosi Megafan; In: Alluvial Fans - A Field Approach (eds) Rachocki A H and Church M (Chichester: Wiley) pp. 151-178.

Gordon I and Heller P L 1993 Evaluating major controls on the Basinal stratigraphy, Pine Valley, Nevada: Implications for syntectonic deposition; Geol. Soc. Amer. Bull. $10547-55$.

Goswami P K and Pant C C 2007 Geomorphology and Tectonics of Kota-Pawalgarh Duns, Central Kumaun SubHimalaya; Curr. Sci. 92 685-690.

Goswami P K and Pant C C 2008 Tectonic evolution of Duns in Kumaun Sub-Himalaya, India: A remote sensing and GIS-based study; Int. J. Remote Sensing 29 4721-4734.

Harvey A M 2002 The role of base-level change in the dissection of alluvial fans: Case studies from southeast Spain and Nevada; Geomorphology 45 67-87.

Harvey A M 2004 The response of dry-region alluvial fans to late Quaternary climatic change; In: Desertification in the Third Millenium (eds) Alsharhan A S, Wood W W, Goudie A S, Fowler A and Abdellatie E M (Rotterdam: Balkema) pp 83-98.

Harvey A M, Mather A E and Stokes M 2005 Alluvial fans: geomorphology, sedimentology, dynamics - introduction. A review of alluvial-fan research; In: Alluvial Fans: Geomorphology, Sedimentology, Dynamics (eds) Harvey A M, Mather A E and Stokes M, Geol. Soc. London, Spec. Publ. 251 1-7.

Hooke R LeB 1968 Steady state relationships on aridregion alluvial fans in closed basins; Amer. J. Sci. 266 609-629.

Hooke R L and Rohrer W L 1977 Relative erodibility of source area rock types from second order variations in alluvial fan size; Geol. Soc. Amer. Bull. 88 1177-1182.

Karunakaran C and Ranga Rao A 1979 Status of exploration for hydrocarbons in the Himalayan region - contribution to stratigraphy and structure; Geol. Surv. India Publ. 41 $1-66$.

Keller E A and Pinter N 1996 Active tectonics: Earthquakes, uplift and landscape (New Jersey: Prentice Hall) $338 \mathrm{p}$.

Lyon-Caen H and Molnar P 1985 Gravity anamolies, flexure of the Indian Plate and the structure, support and evolution of the Himalaya and Ganga basin; Tectonics 4 513-538.

Melton M A 1965 The geomorphic and palaeoclimatic significance of alluvial deposits in Southern Arizona; J. Geol. 73 1-38.

Mohindra R, Parkash B and Prasad J 1992 Historical geomorphology and pedology of the Gandak Megafan, Middle Gangetic Plains, India; Earth Surface Process Landforms 17 643-662.

Nakata T 1972 Geomorphic History and Crustal Movements of the Foot-hills of the Himalaya; Tohoku University Science Reports, 7th Series, Japan 22 39-177.

Nakata T 1989 Actives faults of the Himalaya of India and Nepal; Geol. Soc. Amer. Spec. Paper 232 243-264.

Parkash B, Kumar S, Someshwar Rao M, Giri S C, Suresh Kumar C, Gupta S and Srivastava P 2000 Holocene tectonic movements and stress field in the western Gangetic Plains; Curr. Sci. 79 438-449.

Pilgrim G E 1910 Preliminary note on a revised classification of the tertiary freshwater deposits of India; Rec. Geol. Surv. India 403 185-188.

Pinter N and Keller E A 1995 Late-Quaternary deformation in northern Owens Valley, California: Geomorphic analysis of tectonic tilt; Geol. Runds. 84 200-212.

Rao M B R 1973 The subsurface geology of the IndoGangetic Plains; J. Geol. Soc. India 14 217-242.

Ritter J B, Miller J R, Enzel Y and Wells S G 1995 Reconciling the roles of tectonism and climate in Quaternary alluvial fan evolution; Geology 23 245-248.

Sastri V V, Bhandari L L, Raju A T R and Dutta A K 1971 Tectonic framework and subsurface stratigraphy of the Ganga basin; J. Geol. Soc. India 12 222-233.

Shukla U K and Bora D S 2003 Geomorphology and sedimentology of Piedmont Zone, Ganga Plain, India; Curr. Sci. 84 1034-1040.

Shukla U K, Singh I B, Sharma M and Sharma S 2001 A model of alluvial megafan sedimentation: Ganga Megafan; Sedim. Geol. 40 105-129.

Shukla U K 2008 Sedimentation model of gravel-dominated alluvial Piedmont fan, Ganga Plain, India; Int. J. Earth Sci. (Geol. Rundsch) doi:10.1007/s00531-007-0261-4.

Silva P G, Harvey A M, Zazo C and Goy J L 1992 Geomorphology, depositional style and morphometric relationships of Quaternary alluvial fans in the Guadalentin Depression (Murcia, Southeast Spain); Z. Geomorph. N.F. 36 325-341.

Silva P G, Goy J L, Zazo C and Bardají T 2003 Faultgenerated mountain fronts in southeast Spain: Geomorphologic assessment of tectonic and seismic activity; Geomorphology 50 203-225.

Singh I B 1996 Geological evolution of Ganga Plain - an overview; J. Palaeont. Soc. India 41 99-137.

Singh I B 2004 Late Quaternary history of the Ganga Plain; J. Geol. Soc. India 64 431-454.

Singh H, Parkash B and Gohain K 1993 Facies analysis of the Kosi Megafan deposits; Sedim. Geol. 85 $87-113$.

Singh V and Tandon S K 2006 Evidence and consequences of tilting of two alluvial fans in the Pinjaur Dun, northwestern Himalayan foothills; Quat. International $\mathbf{1 5 9}$ $21-31$.

Sinha R, Tandon S K, Gibling M R, Bhattacharjee P S and Dasgupta A S 2005 Late Quaternary geology and alluvial stratigraphy of the Ganga Basin; Him. Geol. 26 $223-240$

Srivastava P, Singh I B, Sharma M and Singhvi A K 2003 Luminescence chronometry and Late Quaternary geomorphic history of the Ganga Plain, India; Palaeogeogr. Palaeoclimat. Palaeoeco. 197 15-41.

Tandon S K 1991 The Himalayan foreland: Focus on Siwalik Basin; In: Sedimentary Basins of India: Tectonic Context (eds) Tandon S K, Pant C C and Casshyap S M (Nainital, India: Gyanodaya Prakashan) pp. 171-201.

Tandon S K, Gibling M R, Sinha R, Singh V, Ghazanfari P, Dasgupta A, Jain M and Jain V 2006 Alluvial valleys of the Ganga Plains, India: Timing and causes of incision; Spec. Publ. SEPM, Tulsa 85 15-35.

Tandon S K, Sinha R, Gibling M R, Dasgupta A S and Ghazanfari P 2008 Late Quaternary evolution of the Ganga Plains: Myths and misconceptions, recent developments and future directions; Golden Jubilee Mem. Geol. Soc. India 66 259-299.

Thakur V C 2004 Active tectonics of Himalayan Frontal Thrust and seismic hazard to Ganga Plain; Curr. Sci. 86 1554-1558. 
Valdiya K S 1976 Himalayan transverse faults and folds and their parallelism with subsurface structures of the northern Indian Plains; Tectonophys. 32 353-386.

Valdiya K S 2003 Reactivation of Himalayan Frontal Fault: Implications; Curr. Sci. 85 1031-1040.

Valdiya K S, Rana R S, Sharma P K and Dey P 1992 Active Himalayan Frontal Fault, Main Boundary Thrust and Ramgarh Thrust in southern Kumaun; J. Geol. Soc. India 40 509-528.
Viseras C, Calvache M L, Soria J M and Fernández J 2003 Differential features of alluvial fans controlled by tectonic or eustatic accommodation space. Examples from the Betic Cordillera, Spain; Geomorphology $\mathbf{5 0}$ $181-202$.

Yeats R S and Lillie R J 1991 Contemporary tectonics of the Himalayan Frontal Fault system: Folds, blind thrusts and the 1905 Kangra earthquake; J. Struct. Geol. 13 215-225.

MS received 30 September 2008; revised 10 January 2009; accepted 16 March 2009 